\title{
FEATURES OF GEOMETRIC CONCEPTS OF ASSISTANT SCHOOL STUDENTS
}

\author{
M.P. Khamidova
}

Phd, Associate Professor Tashkent State Pedagogical University, Uzbekistan

F. Umirzoqova

2nd Year Master's Student Tashkent State Pedagogical University, Tashkent, Uzbekistan

\section{ABSTRACT}

This article describes the characteristics of auxiliary students in the development of geometric concepts. The importance of using visual aids in the study of geometric material has been highlighted.

KEYWORDS: - Geometric material, correctional pedagogy, individual and differential approach, geometric shape, mathematical concept.

\section{INTRODUCTION}

The development of geometric imagination of secondary school students is of great practical, vital and corrective educational importance.

The study of geometric materials plays an important role in the theoretical and practical issues of correctional pedagogy. In the system of correctional pedagogy, the main focus is on the formation of simplified mathematical concepts.

In studying the learning of geometric materials by mentally retarded children, we relied on the principles of taking into account the specifics of cognitive processes, individual and differential approach, complexity, visualization, going from simple to complex.

The principle of demonstration is used in the development of logical-abstract thinking, emotional perception, helping to consolidate knowledge and skills. The next step in implementing the principle of demonstration in the education of mentally retarded children is to find a way to move from concrete thinking to abstract thinking. This issue is directly related to the issue of developing students' speech.

From the results of the research, we were able to make sure that students know the geometric shapes they use in their daily learning process. But the angle, the perception of cuts is more slowly developed. Skills and competencies are 
CURRENT RESEARCH JOURNAL OF PEDAGOGICS 2(12): 68-71, December

2021 DOI: https://doi.org/10.37547/pedagogics-crjp-02-12-14

ISSN 2767-3278

(C)2021 Master Journals

Crossref do: 81 Google

Accepted 15 th December, 2021 \& Published 20 th December, 2021

not sufficiently developed due to the infrequent use of corner types in speech. It is a good idea for the teacher to use these concepts more often during the day, in the classroom, and to conduct questions and answers with the students.

Examination of the geometric imagination of secondary school students showed that in these children geometric imagination is formed much later than in normally developing students and differs qualitatively from their imagination.

\section{THE MAIN FINDINGS AND RESULTS}

It is more difficult to introduce the concepts of angle, section, $\mathrm{cm}, \mathrm{dm}$, because it is much more difficult for children to grasp these concepts. It is important to take into account the geometric imagination of children when choosing a teacher.

In mentally retarded students, the concept of geometry as a logical unit of knowledge is closely related to the expanded representation of the object. Therefore, identifying geometric representations in students is the first and most important step in concept formation. When learning new geometric material, students should be given a series of prepared exercises that will help them repeat the questions they have learned in their memory. Preparatory exercises should be presented at the beginning of the year, quarterly, in class. This is due to the fact that geometric material is studied in conjunction with arithmetic.

It takes a long time to study geometric material. Students forget a few lessons they have taken or haven't used in a long time. Therefore, in the study of new questions specific to geometry, preparatory exercises are very important, not only to return to the previous learning, to ensure a gradual transition from the known to the unknown, but also to give a given or The purpose of these concepts is to inform students about geometry and to draw their attention to it..
Unlike mentally retarded students, mentally retarded students can only learn a small amount of new material in a single lesson. It will take some time for them to receive and review the information they have received. Therefore, the study material should be presented in small sections, distinguishing important, basic, significant features. Dividing the material into sections helps students to understand concepts, definitions, and rules that are a bit difficult to understand. Exercises used at a certain stage help students with intellectual disabilities to accept the geometric material they are learning to create a specific algorithm and to form the general rules of operation in the direction.

For mentally retarded students, analogy exercises are used to reinforce geometric knowledge in the first place, that is, to introduce a new concept. In addition, students are required to do a large number of the same exercises. For example, students are asked to calculate a large number of perimeters to gain a solid understanding of the concept of polygonal perimeter.

In the study of geometric material, special attention is paid to teaching using a variety of visual aids. Exercises based on ready-made drawings using figure models, posters, diagrams, folding modeling, construction, reconstruction of geometric figures are of great correction. A variety of guidelines should be used to study geometric material. These include demonstration, general-class models of geometric shapes made of colored cardboard or thick paper, posters with shapes, diagrams, and drawings on the board. Also, personal instructions are required. These include geometric games: lotto, mosaic, paper ribbons, sticks of different lengths, paper figures and their parts. When explaining the content of geometric material to mentally retarded children, great care should be taken to develop in them an initial understanding of the shape, size, and spatial 
CURRENT RESEARCH JOURNAL OF PEDAGOGICS 2(12): 68-71, December

2021 DOI: https://doi.org/10.37547/pedagogics-crjp-02-12-14

ISSN 2767-3278

(C)2021 Master Journals

Crossref do: 81 Google

Accepted 15th December, 2021 \& Published 20 th December, 2021

location of various objects. To this end, it is important to systematically include materials that allow students to develop their spatial imagination during the preparation period.

\section{Conclusion}

Thus, mentally retarded children need to use teaching aids to learn and shape geometric materials. In the process of studying geometric material, students develop intelligence and attention. They learn to classify, classify, and compare geometric shapes. Students develop the ability to analyze and synthesize, to think logically about generalization, to develop mental activity. Students' speech is enriched with special geometric terms, expressions, and vocabulary is activated.

Acquiring measurement skills, working with drawing triangles and drawing tools improves fine muscle movement, develops independence and confidence in students.

All of this will help to solve the problem of correcting the cognitive and emotional will of students with intellectual disabilities.

\section{REFERENCES}

1. Ek V.V. Teaching mathematics to students of elementary grades of special (correctional) educational. Institutions of the VIII type: a manual for the teacher / V.V. Eq. - 2nd ed., Rev. - M .: Education, 2005

2. Khamidova, M. P. (2021). DEVELOPMENT

OF COLLECTIVE ACTIVITY OF SPECIALIZED ASSISTANT SCHOOL STUDENTS ON THE BASIS OF DIDACTIC GAMES IN MATHEMATICS. CURRENT RESEARCH JOURNAL OF PEDAGOGICS,
2(11), 134-137.

3. M. I. Sagatov, M. P. Xamidova. Matematika o'qitish maxsus metodikasi. $\mathrm{T}$.: Nodirabegim, 2021

4. Khamidova, M. P. (2021). DEVELOPMENT OF COLLECTIVE ACTIVITY OF SPECIALIZED ASSISTANT SCHOOL STUDENTS ON THE BASIS OF DIDACTIC GAMES IN MATHEMATICS. CURRENT RESEARCH JOURNAL OF PEDAGOGICS, 2(11), 134-137.

5. Perova MI Methods of teaching mathematics in a special (correctional) school of the XIII type: Textbook. For stud. defect, fac. ped. universities. - M .: Humanit. ed. Center VLADOS, 2001.

6. Khamidova, M. P. (2019). Developing Mathematical Knowledge of Mentally Retarded Schoolchildren Using Computer Games. Eastern European Scientific Journal, (1).

7. Zakhlebny A.N. School and problems of nature protection. -M.,: Pedagogy, 1981- p. 6-48

8. Musaeva, N. S., \& Khamidova, M. P. (2020). Speech development in elementary school students and ways to develop vocabulary. International Journal of Psychosocial Rehabilitation, 24(6), 289-296.

9. Zvereva I. D. General methods of teaching biology.-M .: Education, 1985.-191 p.

10. Umirzoqova, N. F. Q. (2021). MEVA VA REZAVOR MEVA O'SIMLIKLARINI KO'PAYTIRISHNI BIOLOGIK ASOSLARI VA MEVA KO'CHATLARINI YETISHTIRISH. Scientific progress, 2(2), 32-36.

11. Edited by ID Zverev, T.I. Surovegina. -M .: Education, 1984-160 p..

12. Stars of spirituality.- T .: "Science" -2000. 
CURRENT RESEARCH JOURNAL OF PEDAGOGICS 2(12): 68-71, December

2021 DOI: https://doi.org/10.37547/pedagogics-crjp-02-12-14

ISSN 2767-3278

(C)2021 Master Journals

Crossref dof 81 Google

Accepted 15th December, 2021 \& Published 20 th December, 2021

13. Pultatova P.M. - Scientific and methodological bases of environmental education in special schools - $\mathrm{T}$.: "Science and Technology" - 2008. 